\title{
Multirezisztens kórokozók előfordulása hematológiai betegeinkben - a rezisztenciatrendek változása
}

\author{
Bicskó Réka Ráhel ${ }^{1,}$, Nyilas Renáta ${ }^{1}$, Szabó Judit ${ }^{2}$, Jóna Ádám ${ }^{1}$, Magyari Ferenc ${ }^{1}$, \\ Szarvas Mariann ${ }^{1}$, Illés Árpád ${ }^{1}$, Gergely Lajos ${ }^{1}$ \\ Debreceni Egyetem, Általános Orvostudományi Kar, Debrecen \\ ${ }^{1}$ Belgyógyászati Intézet, Hematológiai Tanszék \\ ${ }^{2}$ Orvosi Mikrobiológiai Intézet
}

\begin{abstract}
A multirezisztens kórokozók jelenléte világszerte egyre nagyobb gondot jelent a kórházakban. A túlzott és indokolatlan, vagy helytelenül megválasztott antibiotikum-kezelések hatására a rezisztens törzsek kiszelektálódnak, és súlyos infekciókat okoznak, ami az immunszuprimált betegekben sokkal kifejezettebb. E probléma megoldására indult 2013-ban a Debreceni Egyetem Klinikai Központ Belgyógyászati Intézet B épület Hematológiai Osztályán az antibiotikumok diverzifikálása. A monoton gyógyszerválasztás tudatos elkerülésének eredményeként egyes multirezisztens törzsek, így a kiterjedt spektrumú béta-laktamáz termelő Escherichia coli (2012-ben 16, 2016-ban 4 eset) és Klebsiella pneumoniae (2012-ben 27, 2016-ban 3 eset) előfordulása csökkent. Ugyanakkor új gond a vancomycinrezisztens Enterococcus spp. megjelenése (2012-ben 1, 2016-ban 6 pozitív tenyésztés), aminek hátterében valószínúleg a Clostridium difficile infekció miatt kezelt esetek számának növekedése áll (2011-ben 2, 2015-ben 11 eset). A helytelen antibiotikum-felhasználás növeli az ápolási költségeket és rontja a fertőzések kimenetelét, ezért nagyon fontos az antibiotikumok tudatos és ésszerű alkalmazása mind egyéni, mind osztályos szinten. Ahhoz, hogy a multirezisztens kórokozók által okozott fertőzésekkel fel tudjuk venni a harcot, nem csak új antibiotikumokra van szükség, hanem új szemléletre is az infekciók kezelésében.
\end{abstract}

Kulcsszavak: multirezisztens, antibiotikum, infekció, immunszuprimált

\section{Multidrug-resistant bacteria in hematology patients - changes in antibiotic-resistance trends}

Multidrug resistant bacteria are one of the most important current threats to public health. Excessive and causeless use of antibiotics can promote development of antibiotic resistance. It can cause dangerous infections, which can be serious in immunocompromised patients. In 2013 in our haematology ward we started to swap and alternate antibiotics selected for unidentified infections. The results of this program have been investigated, including changes in efficacy of the most commonly used antibiotics, as well as the frequency of multidrug resistant microbes. Our research revealed a tendency towards decreasing prevalence regarding extended-spectrum beta-lactamase-producing Escherichia coli (in 2012, 16 positive cultures, in 2016, only 4 cases) and Klebsiella pneumoniae (in 2012, 27 cases, in 2016, only 3 cases). The occurrence of vancomycin-resistant enterococci (VRE) continues to be an escalating problem (in 2012, only 1 case, in 2016, 6 cases). The number of Clostridium difficile cases significantly increased ( 2 cases in 2011 and 11 cases in 2015), partially explaining the increase in VRE frequency. The struggle to gain the upper hand against multidrug resistant bacteria continues to this day and it is important to cautiously use the available antibiotics not to increase the multi-resistant bacterial strains in the inpatient populations.

Keywords: multiresistant, antibiotics, infection, immunocompromised

(Beérkezett: 2018. október 15.; elfogadva: 2019. február 9.)

Rövidítések

ESBL $=$ kiterjedt spektrumú $\beta$-laktamázok; EUCAST $=$ The European Committee on Antimicrobial Susceptibility Testing;
MACI = multirezisztens Acinetobacter baumannii; $\mathrm{MRSA}=$ methicillinrezisztens Staphylococcus aureus; VRE = vancomycinrezisztens enterococcus

@ Levelezési cím: Dr. Bicskó Réka Ráhel, 4032 Debrecen, Nagyerdei krt. 98.; Tel.: +36-30/1818375, E-mail: bicskorekaa@gmail.com 


\section{Bevezetés}

A multirezisztens kórokozók elleni harc égető feladattá vált az egészségügyben. A penicillin felfedezésével indult az antibiotikum-éra, és lehetőség nyílt a fertőzések mikrobiológiai okának megszüntetésére. Az elmúlt évtizedek antibiotikum-felhasználási szokásai miatt azonban ez egyre nehezebb feladatnak bizonyul. A humán gyógyászatban a helytelen antibiotikum-használat alatt e szerek túlzott vagy szükségtelen használatát értjük, az alul- vagy túldozírozást, a nem megfelelő időtartamban való alkalmazást és a farmakokinetikai és farmakodinámiai sajátosságok figyelmen kívül hagyását. Az antibiotikumok széles körü alkalmazása az orvosláson kívül elterjedt az állattenyésztésben is. $\mathrm{Ez}$ a gyakorlat nagyban befolyásolja a humán gyógyászatot is, hiszen az állatok által hordozott rezisztens mikrobák az élelmiszerláncon keresztül emberre is átterjedhetnek. A rezisztencia lehet természetes és szerzett. Klinikai szempontból ez utóbbi a fontosabb, lényege az érzékenységi spektrum megváltozása. Négy fó mechanizmusa ismert: a kötőhely módosítása, enzimatikus inaktiválás, aktív efflux és a sejtfal-permeábilitás csökkenése [1]. A multirezisztens kifejezést azokra a kórokozókra alkalmazzuk, amelyek több olyan antibiotikumcsoportba tartozó szerrel szemben is ellenállóak, amelyekre a kórokozónak érzékenynek kellene lennie. Ezt minden multirezisztens baktérium esetében külön definíció írja le. Bár a rezisztencia problémaköre minden kórokozó csoportot (baktériumok, vírusok, gombák) érint, a legnagyobb jelentőséggel egyes baktériumok antibiotikumokkal szemben kialakult rezisztenciája bír hazánkban és világszerte egyaránt [2].

A multirezisztens kórokozók rendkívül megnehezítik az infekciók kezelését. Egyrészt rontják a fertőzések kimenetelét, másrészt megnyújtják a kórházi kezelés időtartamát, ezzel pedig jelentősen megnövelik az ápolási költségeket. A hematológiai betegek csoportja különösen veszélyeztetett a multirezisztens infekciókkal szemben, hiszen esetükben jelentős faktor a tartós immunszuprimált állapot is, ami az intenzív kemoterápiás kezelések és a biológiai, célzott terápiák megjelenésével egyre kifejezettebbé válik. Egyes onkológiai és onkohematológiai kezelések kapcsán a neutrophil granulocyták abszolút száma nagymértékben csökken, ami elsősorban a bakteriális fertőzések kockázatának növekedését okozza. A lázas neutropéniás esetek nagy részében az antitumorkezelést is szükséges halasztani, ami viszont veszélybe sodorja a terápia pozitív kimenetelét és a gyógyulást [3]. Ezért e betegek körében egyaránt nagy hangsúlyt kell fektetni az általános és az antimikróbás profilaxisra. Esetükben figyelembe kell venni, hogy láz megjelenésekor elsősorban infekció valószínüsíthető, így még a tenyésztési eredmények kézhezvétele előtt empirikus antibiotikumterápiát kell indítani [4]. Ez azt jelenti, hogy az adott kórképet legnagyobb valószínüséggel okozó mikrobák spektrumát lefedő antibiotikumot alkalmazunk, amelyet később a tenyésztési eredménynek megfelelően módosí- tunk. Az empirikus terápia elmaradása a halálozást nagymértékben növeli, emiatt elengedhetetlen az erre vonatkozó általános elvek, valamint az antibiotikumok és a kórokozók érzékenységének pontos ismerete. Ennél is nagyobb hangsúlyt kap a helyi viszonyok állandó és folyamatos elemzése, a célzott surveillance, amihez nélkülözhetetlen a társszakmákkal való szoros együttmüködés. A hematológiai betegek tehát fokozottan veszélyeztetettek a multirezisztens kórokozókkal szemben, így különösen nagy figyelmet kell fordítani a kezelésük során az infekciós állapotokra, amihez elengedhetetlen az antibiotikumok körültekintő alkalmazása mind egyéni, mind osztályos szinten.

2012. július 1-től a Debreceni Egyetem Klinikai Központ Belgyógyászati Intézet $B$ épületében egyesült a megye és a régió hematológiai betegeinek ellátása. Ekkor a helyi viszonyok mikrobiológiai elemzése után elindult az antibiotikumok tudatos diverzifikálása, ami a tartós szelektív nyomás kialakulását volt hivatott megelőzni.

\section{Célkitűzés}

A vizsgálatunk célja az volt, hogy meghatározzuk a fentiek szerint történő antibiotikum-felhasználás következményeit, eredményeit a multirezisztens kórokozók előfordulásának és az antibiotikumok hatékonyságának függvényében.

\section{Anyagok és módszerek}

A vizsgálatunk a 2011 és 2016 közötti időszakot fedi le, mely során összesen 1984 pozitív mintavételből származó adatot elemeztünk. A minták a Debreceni Egyetem Belgyógyászati Intézet B épületének Hematológiai osztályairól származtak, és az Orvosi Mikrobiológiai Intézetben kerültek feldolgozásra. A tenyésztés céljából levett vérmintákat hemokultúra palackokba (aerob, anaerob) vettük le, melyek a laboratóriumban hemokultúra automatába (Becton-Dickinson, New Jersey, USA) kerültek, inkubálásuk öt napig tartott. Az automata pozitív jelzése esetén a palackokból néhány milliliter vért kivettünk, Gram-szerint festett kenetet készítettünk, majd az izolátumokat species szinten is meghatároztuk, és direkt érzékenységi vizsgálatot végeztünk. A natív mintákat (köpet, bronchusváladék) steril tartályban küldtük be, melyekből kalibrált kaccsal történt a kioltás a csíraszámmeghatározás miatt. A székletmintákat is steril tartályban küldtük be. A sebváladék-, orr-, garat-, fülváladékmintákat steril tamponnal vettük le, és transzport közegben, szobahőmérsékleten juttattuk el a laboratóriumba. A minták feldolgozása a Manual of Clinical Microbiology (11th Edition, ASM Press, Washington DC, USA, 2015) alapján, az érzékenység meghatározása az EUCAST szerint történt. Az adatokat a MEDBAKTER laboratóriumi program és a Medsolution betegdokumen- 
tációs programból nyertük ki. Az adatokat a Microsoft Excel programmal dolgoztuk fel és az ábrákat azzal készítettük.

2013-ban indult az antibiotikum-használat tudatos modifikálása, melyben az empirikusan alkalmazott antibiotikumokat és antibiotikum-csoportokat is váltogattuk. $\mathrm{Az}$ új antibiotikum-rendelési gyakorlat során általában vagy egy béta-laktám csoportba tartozó szert alkalmaztunk, például cephalosporint, carbapenemet vagy egy fluoroquinolont. Esetenként ezt egészítettük ki aminoglikoziddal, mint pl. a ceftazidim/amikacin-kombináció esetében. Az empirikusan alkalmazott széles spektrumú antibiotikumok közül a meropenemet, piperacillin-tazobactámot és a cefepimet használtuk. Időszakosan egy-egy kombinációt igyekeztünk előtérbe helyezni. Amennyiben sikerült pozitív tenyésztési eredményt kapni, a mikrobiológiai tenyésztések függvényében szúkítettük a spektrumot, de-eszkalációs terápiát végeztünk.

A kapott adatokból vizsgáltuk a leggyakrabban alkalmazott antibiotikumok hatékonyságát, a multirezisztens kórokozók százalékos előfordulását az összes pozitív mintavételhez képest és a törzsön belül is, illetve a fekvőbeteg esetszám változásának fentiekre gyakorolt hatását.

\section{Eredmények}

2011 és 2016 között összesen 9985 beteget kezeltünk, ez idő alatt 688 betegtől összesen 1984 pozitív mintát nyertünk. A vizsgált időintervallum alatt folyamatosan nőtt osztályunkon a fekvőbeteg-esetszám. Míg 2011-ben 1117 fekvőbeteget kezeltünk, 2016-ban ennek majdnem a dup-
1. táblázat. A klinikánkon ellátott betegek és a pozitív mintavételek száma az egyes években

\begin{tabular}{lcc}
\hline Év & Betegszám & Mintavétel \\
\hline 2011 & 1117 & 211 \\
2012 & 1467 & 380 \\
2013 & 1599 & 323 \\
2014 & 1700 & 343 \\
2015 & 1996 & 382 \\
2016 & 2106 & 345 \\
\hline
\end{tabular}

láját, 2106 beteget (1. táblázat). A 2011-2012 közötti időszakban azt tapasztaltuk, hogy a fekvőbeteg-esetszám mellett jelentős mértékben megemelkedett a multirezisztens baktériumok száma is (2. táblázat), ezért követni kezdtük ezeket az értékeket, és az antibiotikumok tudatos felhasználását is igyekeztünk ehhez igazítani.

A tenyésztési eredmények alapján a leggyakoribb baktériumok - minden évben és összesítve is - a Staphylococcus epidermidis és az Escherichia coli voltak, de jelentős az egyéb staphylococcusok és az enterococcusok száma. A Gram-negatívok közül pedig a Klebsiella pneumoniae és a Pseudomonas aeruginosa fordult elő nagy számban. A különböző Candida fajok is említésre méltóak (1. ábra).

$\mathrm{Az}$ antibiotikumok hatékonyságát illetően a legkritikusabb a 2012-es év volt. Az antibiotikumok időszakos alkalmazása és egyes szerek lehetőség szerinti tudatos kerülése kezdetben eredményesnek tünt, a 2013-as év adatai szerint valamennyi vizsgált antibiotikummal szemben

2. táblázat. A multirezisztens kórokozók évenkénti előfordulása 2011 és 2016 között

\begin{tabular}{lcccrrr}
\hline Kórokozó & 2011 & 2012 & 2013 & 2014 & 2015 & 2016 \\
\hline ESBL-termelö E. coli & 5 & 16 & 2 & 2 & 18 & 4 \\
ESBL-termelő Klebsiella spp. & 7 & 27 & 7 & 11 & 4 & 3 \\
MACI & 3 & 9 & 3 & 2 & 10 & 13 \\
MRSA & 1 & 10 & 5 & 11 & 17 & 5 \\
Carbapenemrez. Pseudomonas spp. & 4 & 4 & - & 1 & 6 & 5 \\
VRE & - & 1 & - & - & 7 & 6 \\
\hline
\end{tabular}

Röviditések: $\mathrm{ESBL}=$ kiterjedt spektrumú $\beta$-laktamázok, MACI = multirezisztens Acinetobacter baumannii; MRSA = methicillinrezisztens Staphylococcus aureus; rez. = rezisztens; VRE = vancomycinrezisztens enterococcus

3. táblázat. Az izolált baktériumoknak egyes fontosabb antibiotikumokkal szemben in vitro mutatott érzékenységének változása 2011 és 2016 között \%-ban kifejezve. A \%-os érték az adott antibiotikumkorongra tesztelt összes minta \%-át mutatja

\begin{tabular}{lcccccc}
\hline & 2011 & 2012 & 2013 & 2014 & 2015 & 2016 \\
\hline Cefepime & 70,5 & 57,0 & 83,6 & 82,7 & 76,0 & 84,0 \\
Piperacillin/Tazobactam & 71,0 & 49,7 & 84,0 & 74,2 & 60,0 & 77,8 \\
Ceftazidim & 66,1 & 55,3 & 81,4 & 79,6 & 70,7 & 83,8 \\
Meropenem & 83,8 & 91,0 & 92,0 & 96,3 & 88,1 & 84,8 \\
\hline
\end{tabular}




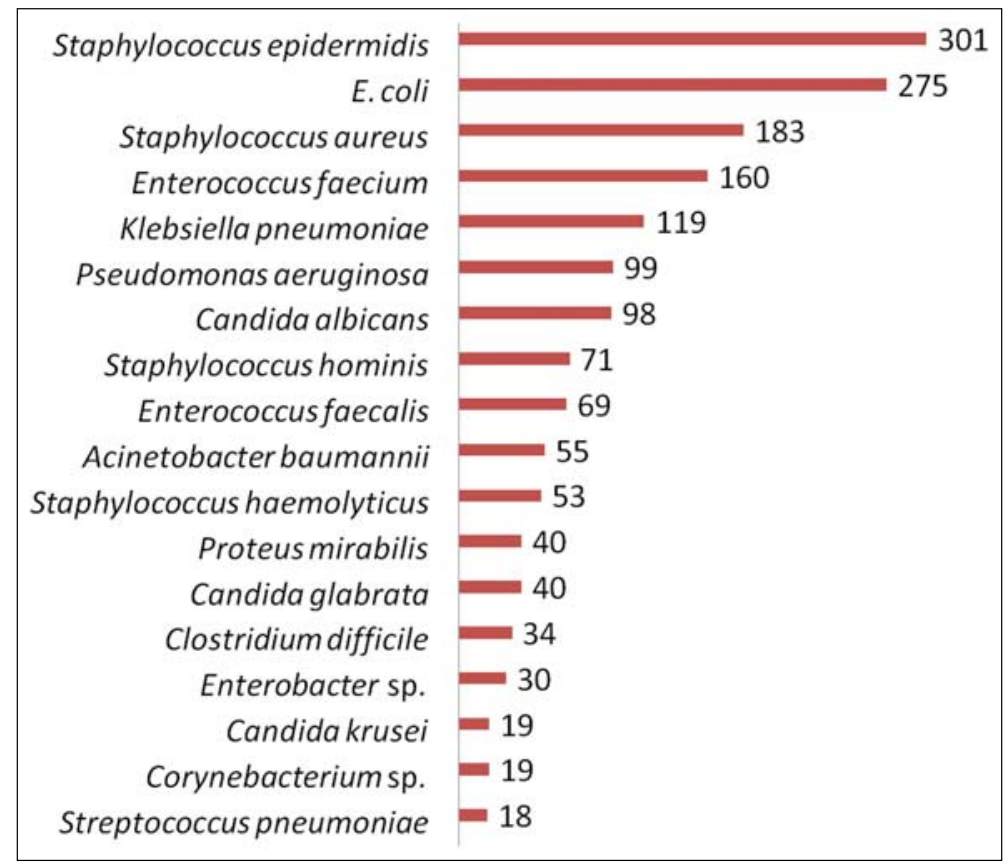

1. ábra. A 2011 és 2016 közötti tenyésztési eredmények alapján az egyes kórokozók száma

növekedett a baktériumok in vitro érzékenysége. 2015-ben azonban ismét lényegesen rosszabb értékeket kaptunk. Ennek hátterében valószínúleg az állt, hogy ebben az évben a saját betegeinken kívül felújítás miatt a Kenézy Kórház általános belgyógyászati betegeit is nagy számban láttuk el. Mindenesetre biztatónak mondható, hogy a 2016-os évre az eredmények ismét javulni kezdtek (3. táblázat).

Megvizsgáltuk az egyes multirezisztens törzsek előfordulását is évekre lebontva. A multirezisztens Acinetobacter baumannii prevalenciája 2012-ben kiugróan magas volt, majd csökkent, ám 2015-től ismét jelentősen növekedett. Az methicillinrezisztens Staphylococcus aureus előfordulási gyakoriságának csúcsa is 2012-re és 2015-re tehető, de azóta itt is csökkenés mutatkozik. A kiterjedt spektrumú $\beta$-laktamázt termelő Escherichia coli esetében is hasonló a helyzet, a 2012-es és 2015-ös évből származnak a legkedvezőtlenebb eredmények. A kiterjedt spektrumú $\beta$-laktamázt termelő Klebsiella pneumoniaenél is a 2012-es évben látszott kiemelkedő esetszám-növekedés, az ezt követő években viszont nagyfokú csökkenés mutatkozik. A fentiekkel szemben aggasztó jelenség a carbapenemrezisztens Pseudomonas spp. növekedése az utóbbi években. Ennek valószínúleg az a magyarázata, hogy egyre több olyan fertőzés kerül megállapításra, ahol be kell vetnünk a carbapenemeket, teret engedve a rezisztencia kialakulásának. Viszonylag új keletű probléma a vancomycinrezisztens enterococcusok elterjedése (4. táblázat)

Ha az adott törzsön belül vizsgáljuk a rezisztencia arányát, akkor is látható, hogy a legkedvezőtlenebb adatok az Acinetobacter baumannii-izolátumok esetében születtek, a törzsek csaknem 100\%-ban multirezisztenssé váltak. A 2015-ös és 2016-os évben az enterococcusok vancomycinrezisztenciája is nagymértékben nőtt, valamint a carbapenemrezisztens Pseudomonas speciesek aránya is jelentősen megemelkedett (5. táblázat).

4. táblázat. Multirezisztens kórokozók \%-os előfordulása az összes mintavételhez viszonyitva 2011 és 2016 között

\begin{tabular}{lcccccc}
\hline Kórokozó & 2011 & 2012 & 2013 & 2014 & 2015 & 2016 \\
\hline ESBL-termelő E. coli & 2,369 & 4,21 & 0,619 & 0,583 & 4,71 & 1,159 \\
ESBL-termelő Klebsiella spp. & 3,317 & 7,1 & 2,167 & 3,206 & 1,047 & 0,869 \\
MACI & 1,421 & 2,368 & 0,928 & 0,583 & 2,617 & 3,768 \\
MRSA & 0,473 & 2,63 & 1,547 & 3,206 & 4,45 & 1,449 \\
Carbapenemrez. Pseudomonas spp. & 1,896 & 1,052 & - & 0,029 & 1,57 & 1,449 \\
VRE & - & 0,263 & - & - & 2,094 & 1,739 \\
\hline
\end{tabular}

Rövidítések: $\mathrm{ESBL}=$ kiterjedt spektrumú $\beta$-laktamázok, MACI = multirezisztens Acinetobacter baumannii; MRSA = methicillinrezisztens Staphylococcus aureus; rez. = rezisztens; VRE = vancomycinrezisztens enterococcus 
5. táblázat. Multirezisztens kórokozók \%-os előfordulása az adott törzsön belül 2011 és 2016 között

\begin{tabular}{lcccrrr}
\hline Kórokozó & 2011 & 2012 & 2013 & 2014 & 2015 & 2016 \\
\hline ESBL-termelö E. coli & 22,7 & 25,40 & 6,4 & 3,8 & 29,00 & 8,80 \\
ESBL-termelö Klebsiella spp. & 41,0 & 75,00 & 77,0 & 41,0 & 30,80 & 17,60 \\
MACI & 37,5 & 69,20 & 100,0 & 25,0 & 100,00 & 100,00 \\
MRSA & 5,6 & 2,63 & 11,9 & 37,9 & 35,42 & 21,70 \\
Carbapenemrez. Pseudomonas spp. & 30,8 & 19,05 & - & 10,0 & 26,08 & 18,52 \\
VRE & - & 4,20 & - & - & 18,20 & 15,40 \\
\hline
\end{tabular}

Röviditések: $\mathrm{ESBL}=$ kiterjedt spektrumú $\beta$-laktamázok, MACI = multirezisztens Acinetobacter baumannii; MRSA = methicillinrezisztens Staphylococcus aureus; rez. $=$ rezisztens; VRE $=$ vancomycinrezisztens enterococcus

\section{Megbeszélés}

Összességében elmondhatjuk, hogy a vizsgált időszakban egyes multirezisztens törzsek - mint ESBL-termeló Gram-negatívok - esetében jelentős csökkenést értünk el. Hazai irodalmi adat nem áll rendelkezésre más hematológiai centrumokból, így nem tudtunk összehasonlítást végezni. Más multirezisztens kórokozóknál kevésbé biztató a helyzet. Az elmúlt években az Acinetobacter baumannii intézményünkben csaknem 100\%-ban multirezisztenssé vált. Ez a baktérium ugyanis szinte valamennyi rezisztenciamechanizmussal rendelkezik, $\beta$-laktamázokat termel, aminoglikozidmodifikáló enzimeket és effluxpumpákat hozott létre. A kórokozó kiemelt jelentőségét alátámasztják a nemzetközi adatok is [5]. A nemzetközi irodalommal párhuzamosan nálunk is új gondot jelent a vancomycinrezisztens enterococcusok egyre növekvő előfordulása, ami valószínúleg a Clostridium difficile toxinpozitív esetek növekedésének, és az emiatt orálisan adott vancomycinterápiának is köszönhető [6]. A jelenség hátterében ugyanakkor állhat a korábban alkalmazott antibiotikum-terápia sikertelensége is. A nehezen kezelhetô fertőzések és az ellenállóbb kórokozók miatt gyakrabban kell széles spektrumú antibiotikumokat - így pl. carbapenemeket - alkalmaznunk. Ennek következtében azonban sajnos azok hatékonysága csökken. A leggyakrabban kitenyészett baktériumokat tekintve is egyeznek eredményeink a külföldi adatokkal [7].

Az eredményeinkből látható, hogy a rezisztens törzsek előfordulása érzékenyen követi az antibiotikum-felhasználást. Bár nagyobb egységekben vizsgálva a különbségek nem olyan számottevőek, ám ha egy-egy kórházi osztály statisztikai adatait elemezzük, a változások máris sokkal hangsúlyosabbá válnak. A rezisztenciaviszonyokban ugrásszerủen következnek be változások, amelyek jelentősen befolyásolják az ápolási költségeket és a fertőzés kimenetelének esélyét is. El kell kerülni, hogy tartós szelekciós nyomás nehezedjen egy osztály flórájára, ehhez pedig megfelelő alapot szolgáltathat a rotációs antibiotikum-felhasználás. Fontos, hogy az orvosok körültekintően alkalmazzák az antibiotikumokat, és törekedjenek a célzott terápiára. Az antibiotikum-terápia megtervezése nehéz feladat. Ha a gyógyszert monoterápiaként alkalmazzuk, könnyebben alakulhat ki a rezisztencia, míg a kombináció nehezebben szelektál, de itt is tartani kell multirezisztens törzsek felbukkanásától. Széles spektrumú vagy kombinált terápia ugyanakkor jobban károsítja a normál flórát $[8,9]$. A mikrobiom megváltozása pedig újabb kutatási eredmények alapján messze ható következményekkel járhat a betegre nézve. Akkor követünk helyes stratégiát, ha minden beteg esetében egyéni szempontok alapján választunk antibiotikumot, figyelembe véve a beteg társbetegségeit, a feltételezett kórokozót, valamint a farmakokinetikai és farmakodinámiai sajátosságokat. Nem lehet kellőképpen hangsúlyozni, hogy egy kórházi osztályon mindig a helyi surveillance eredményei alapján kell megtervezni a kezelést. A penicillin felfedezése óta eltelt több mint 80 év alatt megközelítőleg 140 hatékony antibiotikum került piacra, de a rezisztenciamechanizmusok terjedésével a gyógyszeripar nem tud lépést tartani. A terápiás fegyvertár néhány új vegyülettel bővült, így például a ceftolozán-tazobaktám a kiterjedt spektrumú béta-laktamáz-termelő kórokozókkal és rezisztens Pseudomonas aeruginosával szemben, a ceftazidim-avibaktám pedig emellett egyes karbapenemáztermelőkkel szemben hatékonynak bizonyult [10]. A jelenleg használható antibiotikumok tárháza azonban véges, illetve egy-egy új antibiotikum kifejlesztése nem akadályozza meg a rezisztencia kialakulását. Az antibiotikumok védelme sokkal nehezebb feladat, mint a használatuk [11]. Éppen ezért az anti-infektív terápiával és a fertőzések gyógyításával kapcsolatban újabb lehetőségekről folynak kutatások. Új irányvonal például, hogy infekciók esetén a mikróbák elpusztítása helyett a gazdaszervezet túlzottan heves válaszának a tompítása legyen a cél [12]. Ígéretes lehetôség a mikrobiom segítségül hívása. A kritikus állapotú, immunszupprimált betegekben több szervet érintő diszbiózis alakul ki, így fölénybe kerülnek a patogén kórokozók, ami prediktív a klinikai kimenetelre nézve [13]. A mikrobiom fontosságát támasztja alá az is, hogy a széklet-transzplantációval Clostridium difficile okozta colitisben már biztató eredmények vannak [14]. Ahhoz, hogy a multirezisztens kórokozók által okozott fertőzésekkel fel tudjuk venni a harcot, nemcsak új antibiotikumokra van 
szükség, hanem új szemléletre is az infekciók kezelésében, ami a meglévő antibiotikumok védelmére és további terápiás lehetőségekre irányul.

Nyilatkozat: A szerzők nyilatkoznak arról, hogy a közlemény más folyóiratban nem jelent meg, és ebben a formában máshová sem került beküldésre. Dr. Bicskó Réka Ráhel mint levelező szerző nyilatkozik, hogy a HematológiaTranszfuziológia szerzői instrukcióit elolvasta. A közlemény végleges változatát valamennyi szerző elolvasta és jóváhagyta.

Anyagi támogatás: A közlemény anyagi támogatásban nem részesült.

Érdekeltségek: A szerzőknek nincsenek érdekeltségeik. Szerzői munkamegosztás: B. R. R., Ny. R. - a kézirat elkészítése; M. F., J. A., I. A., G. L. - a kézirat javítása; Sz. M. - az adatok feldolgozása; Sz. J. - a mikrobiológiai adatok szolgáltatása, a kézirat javítása; G. L. - a kézirat végső ellenőrzése.

\section{Irodalom}

[1] Munita JM, Arias CA. Mechanisms of antibiotic resistance. Microbiol Spectr. 2016; 4(2). DOI: 10.1128/microbiolspec.VMBF-00162015.

[2] Hungarian National Center of Epidemiology Methodological Letter about the prevention of multidrug resistant bacteria associated infections. [Módszertani levél a multirezisztens kórokozók által okozott fertőzések megelőzéséről], Országos Epidemiológiai Központ 2016. www.oek.hu/oekfile.pl?fid=6619. Accessed on 2019. 01. 31. [Hungarian]

[3] Sinkó J. Treatment and prevention of the infection in neutropenic cancer patients. [A neutropeniás onkológiai beteg infekcióinak kezelése és megelőzése.] Magyar Onkológia 2011; 55: 155-163. [Hungarian]
[4] Tóth E, Hajdú E, Piukovics K, et al. Presence of bloodstream infection-causing bacteria in patients with acute leukemia [Véráramfertőzést okozó baktériumok előfordulása akut leukémiás betegeknél]. Orvostudományi Értesítő 2007; 80: 32-34. [Hungarian]

[5] Lee C-R, Lee JH, Park M, et al. Biology of Acinetobacter baumannii: Pathogenesis, antibiotic resistance mechanisms, and prospective treatment options. Front Cell Infect Microbiol. 2017; 7: 55. DOI: $10.3389 /$ fcimb.2017.00055.

[6] Benamu E, Deresinski S. Vancomycin-resistant enterococcus infection in the hematopoietic stem cell transplant recipient: an overview of epidemiology, management, and prevention [version 1; referees: 3 approved] F1000Research. 2018, 7(F1000 Faculty Rev): 3. DOI: 10.12688/f1000research.11831.1.

[7] Gomes F, Teixeira P, Oliveira R. Mini-review: Staphylococcus epidermidis as the most frequent cause of nosocomial infections: old and new fighting strategies, Biofouling 2014; 30: 131-141. DOI: 10.1080/08927014.2013.848858.

[8] Barcs I. Antibiotic sensitivity and resistance [Antibiotikum-érzékenység és rezisztencia] In: Mikrobiológiai füzetek 2. Semmelweis Egyetem, Egészségtudományi Kar, Népegészségtani Intézet, Budapest, 2009. [Hungarian]

[9] Gori F, Iredell J, Beardmore RE, et al. Antibiotic cycling and antibiotic mixing: Which one best mitigates antibiotic resistance? Mol Biol Evol. 2017; 34: 802-817.

[10] Sinkó J. Clinical aspects of severe infections caused by antibioticresistant Gram-negative bacteria. The Empire strikes back? [Antibiotikumokkal szemben ellenálló Gram-negatív baktériumok okozta súlyos fertôzések a klinikus szemével. A Birodalom visszavág?] Orv Hetil. 2017; 158: 1528-1534. [Hungarian]

[11] Spellberg B, Gilbert DN. The future of antibiotics and resistance: A tribute to a career of leadership by John Bartlett. Clin Infec Dis. 2014; 59(S2): S71-75.

[12] Spellberg B. The future of antibiotics. Crit Care 2014;18: 228. DOI: $10.1186 / \mathrm{cc} 13948$.

[13] Akrami K. The microbiome of the critically ill patient. Curr Opin Crit Care 2018; 24: 49-54.

[14] Kelly CR. Update on FMT 2015: Indications, Methodologies, Mechanisms and Outlook. Gastroenterology 2015; 149: 223-237.

A cikk a Creative Commons Attribution 4.0 International License (https://creativecommons.org/licenses/by/4.0/) feltételei szerint publikált Open Access közlemény, melynek szellemében a cikk bármilyen médiumban szabadon felhasználható, megosztható és újraközölhető, feltéve, hogy az eredeti szerző és a közlés helye, illetve a CC License linkje és az esetlegesen végrehajtott módosítások feltüntetésre kerülnek. (SID_1) 